\title{
Odpadnutie od spoločenstva s Katolíckou cirkvou formálnym úkonom*
}

Vojtech Vladár

Až do 27. novembra 1983, ked’ nadobudol účinnost’ platný Kódex kánonického práva, univerzálne kánonické právo nepoznalo formálne odpadnutie od Katolíckej cirkvi ako špecifický inštitút, s ktorým by spájalo osobitné právne účinky. Výnimky Kódexom ustanovené napokon zostali v platnosti do 8. apríla 2010, ked' došlo k ich zrušeniu prostredníctvom motu proprio Omnium in mentem pápeža Benedikta XVI. (Benedictus, 2005-2013) z 26. októbra 2009. Tento vývoj predpokladali viacerí kánonisti, ktorí od promulgácie platného Kódexu poukazovali na neopodstatnenost' takejto právnej úpravy a nevyhnutnost' zmien. Možno preto konštatovat', že tento inštitút sa v praxi neosvedčil, čo viedlo po takmer dvadsiatich siedmich rokoch $\mathrm{k}$ návratu $\mathrm{k}$ dôslednému uplatňovaniu zásady "raz katolík, navždy katolík“ (semel catholicus, semper catholicus, respektíve semel baptizatus, semper catholicus). ${ }^{1}$ I ked' sa jeho kánonickoprávne účinky týkali predovšetkým oblasti kánonického manželského práva (clausulae defectionis), zároveň z nich bolo možné dedukovat jeho celkové koncepčné poňatie, ktoré spočívalo v snahe vyjst' v ústrety odpadlíkom. Aj napriek jeho zrušeniu, k vystúpeniam z Katolíckej cirkvi dochádza nad’alej, o čom vypovedajú najmä štatistiky diecéz niektorých, najmä európskych štátov. ${ }^{2}$ Jedným zo svetskoprávnych účinkov (prostredníctvom štátoprávneho správneho aktu) takéhoto úkonu je totiž i oslobo-

* Článok je výstupom z vedeckého projektu VEGA s názvom „Koncept prirodzeného práva a jeho princípov vo vývoji práva, so zameraním na procesnoprávne princípy a procesnú spôsobilost' v rímskom a kánonickom práve", registrovaného pod číslom 1/1006/15. Prednesený bol dňa 23. septembra 2016 na medzinárodnej vedeckej konferencii Trnavské právnické dni (Dies iuris Tyrnavienses), ktorá sa uskutočnila na Právnickej fakulte Trnavskej univerzity v Trnave v rámci Sekcie rímskeho a cirkevného práva s ústrednou témou „Personálna pôsobnost rímskeho a kánonického práva a jej presahy".

1 Porov. kán. 87 CIC/1917; 11 CIC/1983; 1490 CCEO/1990 a Lumen gentium 14-15, in AAS 57 (1965): 5-75. Bližšie k tejto problematike pozri napríklad Jozef PejšKA, Církevní právo I., Ústavní právo církevní, Semily: Nákladem vlastním, 1932, s. 66-67.

2 Porov. napríklad http://dbk.de/imperia/md/content/schriften/dbk5.arbeitshilfen/ah_ 231.pdf. 
denie sa od cirkevnej dane v krajinách, v ktorých sa jej platenie spája $\mathrm{s}$ členstvom $\mathrm{v}$ niektorej z registrovaných cirkví alebo náboženských spoločností. Po dôkladnej analýze relevantných inštitútov je však zrejmé, že takéto konanie nemusí v každom prípade reflektovat skutočnú túžbu po zbavení sa členstva v Cirkvi v osobnom alebo duchovnom rozmere. Celkom prirodzene, s vystúpením z Katolíckej cirkvi sa spájajú aj viaceré teologické a doktrinálne závery, upozorňujúce predovšetkým na vonkajšie prerušenie cirkevného spoločenstva (communio ecclesiastica), ktoré sa v rovine práva prejavujú v sankčnom postihu takto konajúcich.

\section{HistorickoprávNe POZAdie}

V prvom latinskom Kódexe kánonického práva z roku 1917 (Codex iuris canonici anno 1917), podobne ako v platnom Kódexe kánonov východných cirkví z roku 1990 (Codex canonum ecclesiarum orientalium), sa pojem odpadnutia od Katolíckej cirkvi formálnym úkonom (actu formali ab Ecclesia Catholica deficere) nevyskytuje vôbec. ${ }^{3}$ Najmä táto skutočnost' poukazuje

3 Napriek tomu sa za prameň kánonu 1117 platného Kódexu, v ktorom sa vyskytuje tento pojem, bežne uvádza kánon 1099, § 1 Kódexu kánonického práva z roku 1917. Ten obsahuje dikciu: „Firmo autem praescripto $\S 1$, n. 1, acatholici sive baptizati sive non baptizati, si inter se contrahant, nullibi tenentur ad catholicam matrimonii formam servandam; item ab acatholicis nati, etsi in Ecclesia catholica baptizati, qui ab infantili aetate in haeresi vel schismate aut infidelitate vel sine ulla religione adoleverunt, quoties cum parte acatholica contraxerint", teda v preklade "Nekatolíci, pokrstení alebo nepokrstení, ak uzavierajú medzi sebou manželstvo, nie sú nikde viazaní zachovaním katolíckej formy jeho uzavretia, ale bez ujmy predpisu $\S 1,1^{\circ}$; rovnako narodení z nekatolíkov, hoci boli pokrstení v Katolíckej cirkvi, ale boli od detstva v heréze alebo schizme alebo v neviere alebo úplne bez náboženstva vychovávaní, ak uzavierajú manželstvo s nekatolíkom". Z toho vyplývalo, že katolíci, ktorí sa narodili z nekatolíkov boli za splnenia zákonom stanovených podmienok vyňatí spod záväzku dodržania kánonickej formy uzavierania manželstva. Čast̉ normatívneho textu („rovnako narodení z nekatolíkov") upravujúca vyššie uvedenú výnimku bola napokon zrušená k 1. januáru 1949 prostredníctvom motu proprio pápeža Pia XII. (1939-1958) z roku 1948, ktorý argumentoval najmä tažkostami pri jej praktickom aplikovaní. Porov. motu proprio Decretum abrogatur alterum comma paragraphi secundae can. 1099, in AAS 40 (1948): 305-306. Z toho teda vyplývalo, že od zákona dodržat katolícku formu uzavierania manželstva oslobodzoval predmetný kánon len tých nupturientov, ktorí boli narodení z rodičov, ktorí boli nekatolíkmi už pri krste dietata, prípadne len jeden z nich, hoci toto dieła bolo katolícky pokrstené, ale nekatolícky od detstva vychovávané (defectus educationis), ako $\mathrm{k}$ tomu bežne dochádza pri miešaných manželstvách. Porov. Ján Duda, Pokus o katolícku cirkevnoprávnu manželskú kazuistiku, Spišské Podhra- 
na snahu zákonodarcu o zavedenie nového inštitútu, ktorý mal na jednej strane napomôct’ odpadlíkom $\mathrm{k}$ ul'ahčenia výkonu prirodzeného práva na manželstvo (ius connubii), a teda pomôct' im, aby nežili v neplatnom manželstve, avšak zároveň bol vo viacerých ohladoch $\mathrm{v}$ rozpore s kánonickou tradíciou (traditio canonica). ${ }^{4}$ Toto ustanovenie sa týkalo troch konkrétnych inštitútov kánonického manželského práva a predstavovalo praktickú výnimku zo zásady stanovenej kánonom 11 Kódexu kánonického práva, podla ktorej sú normami rýdzo cirkevného (l'udského) práva viazaní všetci, ktorí boli pokrstení v Katolíckej cirkvi alebo do nej prijatí, dovŕšili siedmy rok života a dostatočne používajú rozum. ${ }^{5}$ Už po promulgácii Kódexu konštatovali viacerí kánonisti až prílišnú vágnost’ úpravy tohto inštitútu a, ked’že zákonodarca neponúkol legálnu definíciu, ani skorú autentickú interpretáciu, očakávali sa viaceré komplikácie pri jeho aplikovaní, čo neskôr potvrdila aj právna a pastoračná prax. ${ }^{6} \mathrm{Ani}$ samotná veda nebola vo vymedzení tohto pojmu zajedno, pričom zhoda neexistovala ani medzi renomovanými kánonistami. ${ }^{7}$

Úvahy o reálnom odstránení výnimiek spojených s existenciou tohto inštitútu i inštitútu samotného sa kontinuálne objavovali už od roku 1997. V nadväznosti na ne bola záležitost̉ najskôr prejednaná na plenárnom zasadnutí Pápežskej rady pre výklad textov zákonov (Pontificium

die: Kňazský seminár biskupa Jána Vojtaššáka v Spišsom Podhradí, 2001, s. 446; John P. Beal - James A. Coriden - Thomas J. Green, New Commentary on the Code of Canon Law, New York: Paulist Press, 2000, s. 1336, a Josef BurYšEK, „,',Ab acatholicis' nati can. 1099 § 2 - důležité rozhodnutí Sv. Stolice AAS1948, pg. 305, " in Časopis katolického duchovenstva, 1948, č. 5, s. 261-263.

4 Porov. Jozef KRAJčI, Vel'ké tajomstvo, Bratislava: TA SR Pressfoto, 1993, s. 75.

5 „Legibus mere ecclesiasticis tenentur baptizati in Ecclesia catholica vel in eandem recepti, quique sufficienti rationis usu gaudent et, nisi aliud iure expresse caveatur, septimum aetatis annum expleverunt." Kán. 11 CIC/1983 a 1490 CCEO/1990. V prípade inštitútu formálneho úkonu odpadnutia od Katolíckej cirkvi tak v podstate išlo o zákonnú výnimku (lex specialis) z ustanovenia kánonu 11 Kódexu kánonického práva z roku 1983 (lex generalis). Porov. Matúš Nemec, „Formálne odpadnutie od katolíckej cirkvi,“ in Zborník z medzinárodnej konferencie Trnavské právnické dni „Nová Európa - výzvy a očakávania: Personálna pôsobnost' rímskeho a kánonického práva a jej presahy“, ed. Vojtech Vladár, Trnava: Trnavská univerzita v Trnave, Právnická fakulta, 2016.

6 Porov. napríklad Norbert Ruf, Das Recht der katholischen Kirche nach dem neuen Codex Iuris Canonici für die Praxis erläutert, Freiburg: Herder, 1983, s. 258-259, a Sabine DemeL, Die kirchliche Trauung - unerläßliche Pflicht für die Ehe des katholischen Christen?, Stuttgart: Kohlhammer, 1993, s. 136.

7 Porov. Damián NĚMec, Manželské právo katolické církve s ohledem na platné české právo, Praha: Krystal OP; Kostelní Vydř́: Karmelitánské nakladatelství, 2006, s. 25. 
consilium de legum textibus interpretandis) z 3. júna 1997, ked' Otcovia najskôr odsúhlasili formuláciu pochybnosti (dubium) a s ním súvisiacej odpovede (responsum) za účelom poskytnutia autentickej interpretácie. $\mathrm{V}$ súvislosti s ňou mali byt๋ v prvom rade preskúmané teologické a doktrinálne prvky a potom tiež právnické formality, ktoré mali byt๋ ustanovené ako nevyhnutné na to, aby mohlo byt๋ vystúpenie z Katolíckej cirkvi kvalifikované ako formálny úkon odpadnutia od nej. ${ }^{8}$ Pred vydaním interpretácie sa v záujme zohladnenia praktických aspektov Pápežská rada obrátila na jednotlivé biskupské konferencie s otázkou ohl’adom ich skúseností s aplikáciou dotknutých noriem. V priebehu dvoch rokov bolo prijatých približne 50 odpovedí, ktoré poväčšine poukazovali na potrebu objasnenia ich presného zmyslu, respektíve odstránenia tohto inštitútu z univerzálneho kánonického práva vôbec. ${ }^{9}$ Osobitne bolo pritom apelované na to, aby boli tieto kauzy zásadne posudzované tak, ako civilné zväzky medzi katolíkmi, ktorí nepristúpili k formálnemu úkonu odpadnutia od Cirkvi, teda ako manželstvá neplatné. ${ }^{10}$ Výsledky konzultácií boli potom predložené novému plenárnemu zasadaniu, ktoré sa konalo 4. júna 1999 a jednoznačne odsúhlasilo návrh uvedený inštitút odstránit', čo bolo potvrdené aj pápežom Jánom Pavlom II. (Ioannes Paulus, 1978-2005) na audiencii z 3. júla 1999.

V nadväznosti na vtedajšiu, ale i dnes aktuálnu situáciu bol d’alší osud formálneho úkonu odpadnutia od Katolíckej cirkvi daný do súvislosti s otázkou vyhlásení katolíkov o vystúpení z Cirkvi v niektorých európskych krajinách, a to najmä v Nemecku, Rakúsku a Švajčiarsku,

8 Porov. Pontificium Consilium de legum textibus, „,Actus formalis defectionis ab Ecclesia catholica," 13 March 2006. Prot. N. 10279/2006, dostupné na http://www.vatican.va/ roman_curia/pontifical_councils/intrptxt/documents/rc_pc_intrptxt_doc_20060313_ actus-formalis_en.html.

9 Porov. Francesco Coccopalmerio, „On Omnium in mentem: The Basis of the Two Changes," L'Osservatore Romano. Weekly Edition in English, 31. 3. 2010, s. 6, dostupné na http://www.ewtn.com/library/CANONLAW/bas2changes.htm.

10 Okrem toho malo byt๋ výslovne demonštrované, že manželstvo je v prvom rade sviatostou, pričom niektorí kánonisti dokonca tvrdili, že doterajšia podoba tohto inštitútu nepriamo podporuje vznik klandestínskych manželstiev (matrimonia clandestina), ktoré boli zakázané ešte Tridentským koncilom (Concilium Tridentinum, 1545-1563). Porov. Ján DudA, Katolícke manželské právo, Spišská Kapitula - Spišské Podhradie: Kňazský seminár J. Vojtaššáka, 1996, s. 203-206, a motu proprio Omnium in mentem, in AAS 102 (2010): 8-10. 
ku ktorým dochádza $\mathrm{v}$ snahe vyhnút sa plateniu cirkevnej dane. ${ }^{11}$ Vo vyššie uvedených troch štátoch má totiž Cirkev charakter verejnoprávnej korporácie, z čoho jej vyplýva i povinnost̉ viest̉ osobitnú evidenciu svojich členov. ${ }^{12}$ Tieto deklarácie katolíci poskytujú priamo správcom dane, bežne ich zároveň adresujúc predstavitel’om partikulárnych cirkví, respektíve sú cirkevným autoritám oznamované priamo štátnymi správnymi orgánmi. Okrem spomenutej Pápežskej rady, premenovanej v roku 1999 na Pápežskú radu pre zákonné texty (Pontificium consilium de legum textibus), analyzovala inštitút formálneho úkonu odpadnutia od Katolíckej cirkvi v kontexte teologických a doktrinálnych aspektov aj Kongregácia pre náuku viery (Congregatio pro doctrina fidei), pričom celkové výsledky boli napokon publikované v obežníku adresovanom všetkým biskupským konferenciám. Ten bol so súhlasom pápeža Benedikta XVI. zverejnený Pápežskou radou 13. marca 2006 a zaslaný predsedom biskupských konferencií. ${ }^{13} \mathrm{Aj}$ vydanie tohto dokumentu, ktorý nemož-

11 Porov. René LöfrLer, Ungestraft aus der Kirche austreten? Der staatliche Kirchenaustritt in kanonistischer Sicht, Würzburg: Echter Verlag, 2007, s. 19n.

12 Na tomto pozadí platí, že $v$ takýchto krajinách je zvláštnym účinkom krstu (alebo úkonu prijatia do Katolíckej cirkvi) vo svetskoprávnej oblasti vznik členstva veriaceho vo verejnoprávnej korporácii podl’a štátneho práva, ktorá môže (Nemecko a Rakúsko), ale tiež nemusí (Švajčiarsko) byṫ z hladiska organizačnej štruktúry totožná s organizačnou štruktúrou Cirkvi. Z toho dôvodu sa v praxi stáva, že okrem snahy zbavit’ sa povinnosti platit cirkevnú daň, je vystúpenie z Katolíckej cirkvi častokrát tiež vyjadrením nesúhlasu katolíkov s jej statusom ako verejnoprávnej korporácie. Na ilustráciu možno uviest', že v Rakúsku bolo právo na vystúpenie z Cirkvi garantované už prostredníctvom známych májových zákonov (č. 49/1868) z 25. mája 1868, v Nemecku pruským zákonom zo 14. apríla 1873, kým Švajčiarsko ho na úrovni spolkovej ústavy zaručuje od roku 1874. Pokial ide o terminológiu zákonodarcu, v Nemecku sa cirkevná daň označuje pojmom „Kirchensteuer“ (cirkevná daň), v Rakúsku „Kirchenbeitrag“ (cirkevný príspevok) a vo Švajčiarsku „Kirchgemeindesteuer“ (cirkevná všeobecná daň). Bližšie k tejto problematike pozri Gerhard RoввERs, „Stát a církev ve Spolkové republice Německo, " in Stát a církev v zemích EU, ed. Gerhard Robbers, Praha: Academia, 2002, s. $63 \mathrm{n}$.

13 Tento obežník bol zverejnený v niekol'kých jazykových verziách (taliansky, anglicky, nemecky, francúzsky, španielsky a portugalsky) v časopise Communicationes. Spolu $\mathrm{s}$ ním boli publikované i d’alšie dokumenty, konkrétne výňatok $\mathrm{z}$ d’akovného listu jednej biskupskej konferencie (v angličtine), list Pápežskej rady pre zákonné texty inej biskupskej konferencii ako odpoved' na pochybnost' ohladom spôsobu hodnotenia písomného oznámenia katolíka cirkevnou autoritou, pokial' s ním nie je možné osobné stretnutie a dialóg (v taliančine), a odpoved' tej istej Pápežskej rady d’alšej biskupskej konferencii ohl'adom oprávnenosti požiadavky centralizácie procesu v diecéznej kúrii (v španielčine). Porov. Communicationes 38 (2006): 170-184. Bližšie k tejto problematike pozri Damián NĚMEC, „Vznik, chápání a pozdější upřesnění právního institutu for- 
no kvôli jeho celkovému koncepčnému poňatiu a najmä nezverejneniu v Aktoch Apoštolskej Stolice (Acta Apostolicae Sedis) označit’ za autentickú interpretáciu s konštitutívnymi účinkami, len prispelo k posilneniu záveru o tom, že inštitút formálneho úkonu odpadnutia od Cirkvi a výnimky s ním spojené by mali byt’ z univerzálneho práva kompletne odstránené. ${ }^{14}$ To bolo napokon reflektované aj počas prác na motu proprio

málního odpadu od katolické církve a jeho dopad na platnost manželství," in Revue církevního práva, č. 3 (2010): 246-247.

14 Porov. kán. 16, § 2 CIC/1983 a 1498, § 2 CCEO/1990. Viacerí kánonisti upierajú tomuto dokumentu charakter autentickej interpretácie, argumentujúc, že nebola publikovaná na spôsob zákona. Zákonodarca však túto povinnost’ vyžaduje jedine v prípade autentickej interpretácie obsahujúcej konštitutívny výklad, ktorý musí byt’ podaný na spôsob zákona (per modum legis). V tomto prípade je, celkom prirodzene, zároveň úplne vylúčená retroaktivita. Autentický výklad na spôsob interpretácie s deklaratórnym významom, teda taký, ktorý interpretuje objektívne jednoznačný normatívny text, ale takúto požiadavku reflektovat nemusí. Samotné prijatie tohto obežníka zo strany viacerých partikulárnych cirkví naznačuje jeho akceptovanie práve v rovine autentickej interpretácie s deklaratórnymi účinkami (napríklad konanie Nemeckej biskupskej konferencie). Charakter deklaratórneho výkladu však spochybňuje celková koncepcia tohto dokumentu, až príliš široký spôsob interpretovania predmetných noriem a opomenutie vyjadrit sa k manželstvám uzavretých odpadnuvšími/neodpadnuvšími katolíkmi v rokoch 1983 až 2006. V takomto prípade by totiž museli byt manželstvá katolíkov, ktorí odpadli/neodpadli od Katolíckej cirkvi formálnym úkonom, spätne posudzované v duchu tejto interpretácie. Ked’že predmetný obežník nebol vydaný na spôsob zákona, jeho záväznost' zostáva otázna a zváženie tohto postupu by spočivalo výlučne na partikulárnych cirkevných autoritách. Analyzujúc tento dokument v duchu jeho interpretačného charakteru a prípadnej povahy prameňa práva však musíme odôvodnene predpokladat jeho záväznost̉ minimálne pre subjekty, ktorým bol adresovaný. Celkom prirodzene, $\mathrm{z}$ dôvodu absencie publikovania nemôže $\mathrm{v}$ jeho prípade íst' o všeobecne záväzný normatívny právny akt, ktoré sa vyznačujú všeobecnostou a abstraktnostou. Profesor Ignác Antonín Hrdina mi v tejto súvislosti prezentoval svoj názor o možnosti ponímat tento obežník v duchu úradného (oficiálneho) výkladu, ktorý má charakter pokynov (instructiones) podla kánonu 34 Kódexu kánonického práva. O správnosti tohto záveru nás presviedča najmä skutočnost', že pokyny nemusia byt๋ riadne publikované, ale stačí, ak sú adresátom nejakým spôsobom sprostredkované, čo je aj prípad tohto dokumentu. I ked' o pokynoch nemožno uvažovat' v duchu formálneho prameňa stricto sensu (chýba im najmä všeobecná záväznost'), napriek tomu sú pre administratívne podriadené orgány, ktorým boli riadne intimované, záväzné. Pokial ide o cirkevných sudcov, ked’že tí sú pri rozhodovaní viazaní len zákonom (na základe opinio communis), s určitostou nie sú de iure povinní zohl'adňovat pokyny určené administratívnym orgánom. Možno ale predpokladat', že tento obežník sudcovia pri svojej rozhodovacej činnosti predsa len aplikovali de facto (ako k tomu dochádza v prípade judikatúry Rímskej Roty). Na základe uvedeného možno zároveň zovšeobecňujúco konštatovat', že Pápežskej rade sa takýmto spôsobom fakticky podarilo prostredníctvom úkonu výkonnej moci (pokyn) vo viacerých partikulárnych cirkvách 
Omnium in mentem, ktorého text bol najskôr preskúmaný na plenárnom zasadaní Pápežskej rady pre zákonné texty zo 16. júna 2009, za predsedníctva kardinála štátneho sekretára. ${ }^{15}$ Všetky dotknuté právne účinky spojené s formálnym úkonom odpadnutia od Katolíckej cirkvi, vrátane inštitútu samotného, boli týmto normatívnym právnym aktom $\mathrm{v}$ rovine univerzálnej legislatívy zrušené.

\section{VYMEDZENIE POJMU „FORMÁLNY ÚKON“}

V platnom Kódexe kánonického práva sa termíny formale a formaliter obvykle používajú $\mathrm{k}$ definovaniu právneho úkonu, ktorý je verejný a zamýšlaný $\mathrm{k}$ vyvolaniu zmeny $\mathrm{v}$ cirkevnom statuse nejakej osoby alebo skupiny osôb. ${ }^{16} \mathrm{Z}$ toho možno zjednodušene dedukovat', že formálny úkon odpadnutia od Katolíckej cirkvi je právnym úkonom dokázatelným vo vonkajšom fóre (forum externum), ktorého zamýšlaným efektom je prerušenie spoločenstva s Cirkvou. ${ }^{17}$ Pri vystupovaní z nej je tiež potrebné zohl'adnit rozdiel medzi morálnou stránkou takéhoto konania a stránkou právnou. Pokial' ide o morálku, významné je už samotné rozhodnutie katolíka opustit Katolícku cirkev, a to aj vtedy, pokial' nebolo nijakým spôsobom prejavené navonok. Z právneho hladiska však platí, že čisto vnútorné úkony nedisponujú žiadnymi právnymi účinkami. ${ }^{18} \mathrm{Aj}$ v prípade inštitútu formálneho úkonu odpadnutia od Cirkvi bolo z noriem univerzálneho práva nevyhnutné v prvom rade aplikovat’ všeobec-

zmenit spôsob aplikácie normatívneho právneho aktu bez toho, aby použila autentickú interpretáciu s konštitutívnym výkladom. Porov. Antonín Hrdina, Kanonické právo, Praha: Eurolex Bohemia, 2002, s. 85-86 a 124-125.

15 Porov. Coccopalmerio, „On Omnium in mentem,“ s. 6, dostupné na http://www. ewtn.com/library/CANONLAW/bas2changes.htm.

16 Tento výraz sa ale používa napríklad tiež k označeniu dekrétu, ktorým získava právnu subjektivitu súkromné združenie veriacich (kán. 322, § 1 CIC/1983). Formálnym dekrétom možno zriadit aj inštitút zasväteného života diecézneho práva (kán. 579 CIC/1983 a 435, §1; 506, § 1 a 566 CCEO/1990), prípadne ho schválit ako inštitút práva pápežského (kán. 589 CIC/1983 a 434; 505, §§ 1 a 2 CCEO/1990). Bližšie k tejto problematike pozri Beal - Coriden - Green, New Commentary on the Code of Canon Law, s. $1336^{247}$.

17 Bližšie k pojmu cirkevného spoločenstva pozri napríklad Zenon GrocholewsKI, „Theological Aspects of the Judicial Activity of the Church," in Incapacity for Marriage: Jurisprudence and Interpretation, ed. Robert M. Sable, Rome: Pontificia Universitas Gregoriana, 1987, s. 5n.

18 Porov. NĚMEc, Manželské právo katolické církve, s. 25. 
né ustanovenia kánonov 11 a 124 . Kým prvý obsahuje predtým spomenuté vymedzenie adresátov kánonickoprávnych noriem rýdzo cirkevného (ludského) práva, druhý kánon spresňuje, že každý právny úkon musí byt๋ vykonaný osobou k nemu spôsobilou a obsahovat to, čo tvorí jeho podstatu, ako aj d’alšie formality a náležitosti právom vyžadované. V tomto kontexte je dôležitý aj $\S 2$ tohto kánonu, ktorý ustanovuje, že za platný sa považuje každý právny úkon riadne vykonaný vo vonkajšom fóre. ${ }^{19}$ Pápežská rada pre výklad textov zákonov napokon svojou odpoved’ou zo 4. januára 1994 tieto závery potvrdila s tým, že formálny úkon odpadnutia od Cirkvi musí byt úkonom striktne osobným, a tak subjekt, ktorý ho koná, musí byṫ k nemu prirodzene i právne schopný. ${ }^{20}$ Okrem toho, musí byt', v súlade $\mathrm{s}$ požiadavkami prirodzeného práva, urobený vedome a slobodne.

Ked’že v prípade právnej úpravy formálneho úkonu odpadnutia od Katolíckej cirkvi išlo o normy, ktoré obsahovali výnimku zo zákona, je potrebné pripomenút, že v súlade s kánonom 18 sa museli vykladat’ striktne. Aj napriek zásadnej aplikácii tohto princípu však zostávali viaceré otázky nevyjasnené. Okrem vyššie uvedených záverov, Pápežská rada pre zákonné texty v spomínanom dokumente z roku 2006 konštatovala, že samotný formálny úkon odpadnutia od Cirkvi sa v zásade líši od iných, tzv. „virtuálnych" foriem verejne známeho alebo verejného zavrhnutia katolíckej viery. ${ }^{21} \mathrm{Na}$ to, aby mohlo íst skutočne o aplikáciu

19 Porov. Stanislav ZvolenskÝ, „Formálne odpadnutie od Katolíckej cirkvi,“ Tribunál 2004, č. 1, dostupné na http://tribunal.kapitula.sk/2004-1/formalne.htm.

20 V dôsledku toho, že u nedospelých absentuje plná spôsobilost' k výkonu práv (kán. 98, § 2 CIC/1983 a 910, § 2 CCEO/1990), nie sú spôsobilí ani k tomuto úkonu. Za takéto osoby ho však nemôžu vykonat' ani ich rodičia. Platí teda, že deti, ktoré boli pokrstené v Katolíckej cirkvi a ktorých rodičia neskôr zapísali do nekatolíckej cirkvi alebo náboženskej spoločnosti, môžu takéto rozhodnutie rodičov schválit, až ked' sa stanú plnoletými. Avšak, aby tak urobili formálnym úkonom, musia mat v tomto ohlade osobitne na zreteli katolícky krst. Porov. kán. 126 CIC/1983 a 933 CCEO/1990. Bližšie $\mathrm{k}$ tejto problematike pozri Beal - Coriden - Green, New Commentary on the Code of Canon Law, s. 1336.

21 Porov. kán. 171, §1, $4^{\circ} ; 194, \S 1,2^{\circ} ; 316, \S 1 ; 694, \S 1,1^{\circ} ; 1071, \S 1,4^{\circ}$ a $\S 2$ CIC/1983 a 953, $\S 1,3^{\circ} ; 976, \S 1,2^{\circ} ; 580 ; 497, \S 1,1^{\circ} ; 551$ a $789,6^{\circ}$ CCEO/1990. Z pohladu teórie kánonického práva totiž na základe kritéria úmyslu subjektu práv rozoznávame formálne a virtuálne úkony. O formálnom úkone hovoríme, ak je úmysel vyjadrený vlastnými slovami, o virtuálnom, ak subjekt prejaví to isté faktickým konaním. Výslovné vyjadrenie úmyslu môže byt' potom priame (explicitné) alebo nepriame (implicitné). Porov. NĚMec, Manželské právo katolické církve, s. 26. Pokial ide o l’udskú vôlu a konanie, je potrebné zohl'adnit navzájom súvisiace pojmy „formálny“ a "materiálny“. Ak si to- 
tohto inštitútu $\mathrm{v}$ kánonickoprávnom rozmere, sa preto z pohladu prejavu vôle v prvom rade požadoval slobodný vnútorný úmysel katolíka opustit Cirkev, ako aj uskutočnenie a prejavenie tohto rozhodnutia. Osoba teda musela dostatočne poznat vlastný objekt právneho úkonu (povaha spoločenstva Katolíckej cirkvi), mat' reálny úmysel Cirkev opustit a byt slobodne rozhodnutá tento úkon (odpadnutie od nej) uskutočnit.. ${ }^{22}$ Vlastnou snahou katolíka preto muselo byṫ rozviazanie pút spoločenstva s Katolíckou cirkvou spočívajúcich na vyznaní viery, sviatostiach a cirkevnom riadení (tria vincula), na základe ktorých je veriaci spôsobilý k prijímaniu cirkevných milostí. ${ }^{23}$ Formálny úkon odpadnutia od Katolíckej cirkvi teda musel mat' viac než len administratívnoprávny charakter a mal byt' ponímaný ako reálne odlúčenie sa od života Cirkvi, pričom $\mathrm{v}$ tomto prípade sa nevyhnutne predpokladal i delikt schizmy, prípadne tiež apostázy alebo herézy. ${ }^{24}$ Ak teda u katolíka pretrvávala vôla zotrvat' v spoločenstve viery, administratívnoprávny úkon opustenia Cirkvi nepredstavoval skutočnú aplikáciu inštitútu formálneho úkonu od-

tiž osoba správne uvedomuje hodnotu svojho rozhodnutia a vedome ho aj uskutoční, hovoríme o formálnom konaní. O formálny skutok ide tiež v prípade, ak subjektívne chápanie zodpovedá jeho objektívnej hodnote a osoba ho uskutočňuje vedome na základe týchto kvalít. V inom prípade hovoríme o skutku v materiálnom zmysle. Ako príklad možno v tomto kontexte uviest̉ rozlišovanie medzi materiálnym a formálnym hriechom. Ak napríklad veriaci vie, že určité konanie je hriešne a aj tak ho vykoná, hovoríme o formálnom hriechu. Ak ale uskutoční objektívne hriešny skutok, avšak o tom, že ide o hriech, nevie, pôjde o hriech materiálny. Porov. ZvolenskÝ, „Formálne odpadnutie od Katolíckej cirkvi,“ Tribunál 2004, č. 1, dostupné na http://tribunal.kapitula.sk/2004-1/formalne.htm. Na základe historického výkladu a názorov niektorých kánonistov možno konštatovat', že pre správnu interpretáciu právnych konštrukcií vymedzujúcich poňatie formálneho úkonu odpadnutia od Katolíckej cirkvi je najdôležitejšie zohl’adnił opozíciu prívlastkov "formálny“ a "virtuálny“. Porov. napríklad Velasio de PAOLIs, „,Alcune annotazioni circa la formula actu formali ab Ecclesia catholica deficere," Periodica 84 (1995): 602-604.

22 Porov. ZvolenskÝ, „Formálne odpadnutie od Katolíckej cirkvi,“ Tribunál 2004, č. 1, dostupné na http://tribunal.kapitula.sk/2004-1/formalne.htm, a NĚMEC, „Vznik, chápání a pozdější upřesnění právního institutu formálního odpadu od katolické církve, " s. 242.

23 Porov. kán. 205 CIC/1983 a 8 CCEO/1990.

24 Kánon 1364 napokon ukladá, podobne ako Kódex kánonického práva z roku 1917, apostatom, heretikom a schizmatikom trest exkomunikácie latae sententiae (nerezervovanej Apoštolskej Stolici). Takto však môžu byt๋ v duchu koncepcie platného Kódexu kvalifikovaní len tí, ktorí boli pokrstení v Katolíckej cirkvi alebo do nej prijatí. Porov. kán. 2314 CIC/1917; 751 a 1364 CIC/1983 a 1436, § 1 a 1437 CCEO/1990. V súvislosti s prejednávaný inštitútom je potrebné tiež uviest', že takýto katolík má na základe kánonu 1071, § 1, 5 zakázané uzavriet manželstvo. Porov. kán. 1071, §1, 5 CIC/1983. 
padnutia od Katolíckej cirkvi. Podobne ním nemusela byt’ ani heréza (či už formálna alebo materiálna), ${ }_{,}^{25}$ schizma alebo apostáza, pokial' neboli navonok konkretizované a prejavené pred cirkevnou autoritou právom stanoveným spôsobom. ${ }^{26}$

Z vyššie uvedeného vyplýva, že v prípade inštitútu formálneho úkonu odpadnutia od Katolíckej cirkvi muselo íst’ o odpadnutie z vlastného rozhodnutia, pričom ho nebolo možné stotožňovat' so životnou situáciou tých, ktorí sa odlúčli od Cirkvi na základe výchovy mimo nej. ${ }^{27}$ Okrem toho, formálne odpadnutie na základe vlastného rozhodnutia prichádzalo do úvahy bud' na základe vyjadrenia vlastného odpadnutia, ale tiež na základe virtuálneho odpadnutia. Mohlo teda k nemu dôjst' bud' na základe jasného a výslovného vyjadrenia vôle opustit Cirkev, alebo na základe určitého spôsobu konania, ktoré $\mathrm{k}$ tomu smerovalo. V každom prípade ale platilo, že takýto úkon musel byt prejavený navonok, t.j. vo vonkajšom fóre. ${ }^{28} \mathrm{Z}$ dikcie dokumentu Pápežskej rady z roku 2006 je navyše zrejmé, že viacerí kánonisti vo svojich úvahách do toho času nedostatočne reflektovali výraz formale $\mathrm{v}$ rozmere nevyhnutnosti zachovania až tak vysokého stupňa formálnosti. Tieto skutočnosti sa v tomto obežníku odzrkadlili najmä v závere, že formálny úkon odpadnutia od Katolíckej cirkvi mal byt’ urobený $\mathrm{v}$ písomnej forme a podliehal osobnej kontrole a overeniu zo strany kompetentnej cirkevnej autority, pred

25 Formálna heréza sa vždy spája s tvrdošijnostou. Krestan si teda je v takomto prípade vedomý, že jeho názor je v priamom rozpore s článkom viery. Pri materiálnej heréze však tvrdošijnost' chýba a skutok pochádza z nevedomosti. Porov. BeAL - CoRIDEN Green, New Commentary on the Code of Canon Law, s. 1575-1577.

26 Bližšie k tejto problematike pozri Ernest CAPARros - Michel Thériault - Jean THorn, Code of Canon Law Annotated, Montréal: Wilson \& Lafleur Limitée, 2004, s. 830.

27 Porov. Duda, Pokus o katolícku cirkevnoprávnu manželskú kazuistiku, s. 46-47. Aj táto a podobné úvahy boli totiž predmetom diskusií počas prípravných prác ku Kódexu kánonického práva z roku 1983. Napokon však boli celkom zavrhnuté a prednost̉ dostal princíp právnej istoty. Ani neusporiadaný život, výchova extra Ecclesiam, ani verejné zavrhnutie katolíckych zásad teda nestačí k tomu, aby bolo takéto konanie kvalifikované ako formálny úkon odpadnutia od Katolíckej cirkvi. Porov. Communicationes 8 (1976): 59-60.

28 Z uvedeného vyplýva, že prejav odpadnutia od Katolíckej cirkvi mohol byṫ bud’ priamy, ked' sa subjekt napríklad vyjadril, že chce opustit katolícku Cirkev, alebo nepriamy, ked' subjekt svoju vôlu vyjadril nepriamo, napríklad tak, že sa chce stat členom Evanjelickej cirkvi. Porov. Zvolenskŕ, „Formálne odpadnutie od Katolíckej cirkvi,“ Tribunál 2004, č. 1, dostupné na http://tribunal.kapitula.sk/2004-1/formalne.htm. 
ktorou mal byt’ vykonaný. ${ }^{29}$ Celkom prirodzene, po vydaní tohto dokumentu boli uvedené závery viac-menej reflektované aj normami partikulárneho kánonického práva, čo bolo zrejme tiež úmyslom univerzálneho zákonodarcu. ${ }^{30}$ Napriek tomu je nevyhnutné pripomenút', že aj ked'

29 Takouto autoritou bol prirodzene ordinár alebo iný vlastný pastier (najčastejšie príslušný farár), ktorí boli, v súlade s požiadavkami univerzálneho práva, výlučne kvalifikovaní k posúdeniu existencie alebo neexistencie úkonu vôle. Pokial' vystupujúci sám nenavštívil príslušnú cirkevnú autoritu, aby jej okolnosti svojho odchodu ozrejmil, mala sa na neho s touto otázkou obrátit samotná cirkevná vrchnosté. Netreba taktiež zabúdat' na to, že takéto konanie malo nielen právnický, ale tiež pastoračný aspekt. I na tomto pozadí možno konštatovat', že formálny úkon odpadnutia od Katolíckej cirkvi zakladal spojenie dvoch elementov - teologického, spočívajúceho $\mathrm{v}$ samotnom obsahu vnútorného úkonu, a právnického, spočívajúcom v jeho vonkajšom vyjadrení vyššie uvedeným spôsobom. Ako sme už spomenuli, s takýmto konaním sa, celkom prirodzene, spájali aj príslušné kánonické tresty. Porov. kán. 1364, §1 CIC/1983 a 1436, $\S 1$ a 1437 CCEO/1990. Pokial ide o požiadavku písomnej formy, viacerí kánonisti poukazujú v kontexte univerzálneho zákonodarstva na značnú nelogickost̉ tohto ustanovenia. Porov. napríklad Edward Peters, „The Formal Act of Defection," dostupné na http://www.canonlaw.info/canonlaw_discus.htm.

30 V tejto súvislosti možno napríklad spomenút konanie Nemeckej biskupskej konferencie (DBK), ktorá vydala už 24. apríla 2006 prehlásenie o tom, že túto interpretáciu je potrebné aplikovat pri zohl'adnení nemeckej právnej tradície. Pre Nemecko je pritom typické dlhodobé stotožňovanie vystúpenia z Cirkvi s úkonom schizmy (schisma purum). Porov. kán. 209 a 751 CIC/1983 a 12 CCEO/1990. Tento záver je napokon v zásade prijímaný aj viacerými významnými kánonistami. Porov. najmä Joseph ListL, „Die Erklärung des Kirchenaustritts,“ in Handbuch des katholischen Kirchenrechts, ed. Joseph Listl - Heribert Schmitz, Regensburg: Verlag Friedrich Pustet, 1999, s. 209-219. Nemecká biskupská konferencia okrem toho konštatovala, že predmetná interpretácia nevytvára žiadne nové právo, ale pridržiava sa platného právneho stavu a potvrdzuje zavedenú právnu prax. Aj z tohto vyjadrenia je tak zrejmé, že obsah tohto obežníka bol v Nemecku akceptovaný v rozmere deklaratórneho výkladu. Podobným spôsobom konala aj Pol'ská biskupská konferencia, ktorá v roku 2008 obdobne vydala k tomuto inštitútu vlastné partikulárne normy. Tie boli, paradoxne, ešte prísnejšie než ustanovenia interpretácie Pápežskej rady. K dôslednému zapracovaniu tohto obežníka došlo najmä v Rakúsku, kde bol v roku 2007 publikovaný v plnom znení v oficiálnom vestníku, na základe čoho sa stal súčastou tamojšieho partikulárneho kánonického práva. Na tomto základe bol zavedený i nový procesnoprávny inštitút opytovacieho konania, ktorého cielom bolo zistenie skutočného úmyslu vystupujúceho odpadnút od Cirkvi. Aj ked’ sa zdá, že vyššie spomenuté biskupské konferencie takýmto spôsobom vyriešili d’alšie praktické uplatňovanie tohto inštitútu na partikulárnej úrovni dostatočným spôsobom, všetko naznačuje tomu, že osobitne sledovali najmä ciel', aby nemuseli nanovo posudzovat manželstvá odpadlíkov z rokov 1983 až 2006. K tomu ich pritom viedla bud' vlastná pohodlnost' alebo presvedčenie o správnom uplatňovaní tohto inštitútu aj pred vydaním spomenutého dokumentu, čo napokon niektoré z nich jasne deklarovali. Je ale otázne, či možno tento záver akceptovat napríklad vo vztahu k Rakúsku, kde bola všeobecne akceptovaná prax, že každé vyhlásenie sa z Cirkvi (aj 
obežník z roku 2006 vyžadoval pre platnostł formálneho úkonu odpadnutia jeho prijatie cirkevnou vrchnostou, tá v skutočnosti posudzovala len splnenie právom stanovených náležitostí (existencia/neexistencia úkonu vôle). ${ }^{31} \mathrm{Až} \mathrm{po} \mathrm{tomto} \mathrm{úkone} \mathrm{bola} \mathrm{cirkevná} \mathrm{autorita} \mathrm{oprávnená} \mathrm{za-}$ značit túto skutočnost’ do krstnej matriky. ${ }^{32}$

v prípade, ak išlo o vystúpenie kvôli neochote platenia cirkevnej dane) bolo kvalifikované ako formálny úkon odpadnutia od nej. Platnost takýchto manželstiev preto zostáva otáznou. Je vysoko pravdepodobné, že práve spôsob praktického uplatňovania tohto inštitútu a právna neistota s ním spojená bola hlavným dôvodom, prečo cirkevný zákonodarca napokon pristúpil k jeho zrušeniu. Porov. RobBers, „,Stát a církev ve Spolkové republice Německo," s. 63n.

31 Na tomto pozadí nemožno súhlasit’ s kánonistami zastávajúcimi názor, že tento pôvodne jednostranný právny úkon sa zmenil na úkon dvojstranný. Aj ked’ totiž bolo povinnostou vystupujúceho katolíka o tomto úkone písomne informovat' cirkevnú autoritu, jej rozhodnutie malo len deklaratórny charakter a pôsobilo spätne k času prezentácie uskutočnenia vnútorného úkonu odpadnutia navonok. Porov. napríklad NĚMEC, „Vznik, chápání a pozdější upřesnění právního institutu formálního odpadu od katolické církve," s. 247. Tento záver potvrdzuje aj postoj niektorých kánonistov, ktorí zastávali aj po roku 2006 názor, že účinky formálneho úkonu odpadnutia od Cirkvi nastávajú už okamihom, ked' k danému úkonu zo strany katolíka došlo, nie okamihom, ked’ o ňom bola písomne informovaná kompetentná cirkevná autorita. Porov. Peters, „The Formal Act of Defection, “ dostupné na http://www.canonlaw.info/canonlaw_discus.htm.

32 Porov. kán. 535, § 2 CIC/1983 a 296, § 2 CCEO/1990. Od nadobudnutia účinnosti motu proprio Omnium in mentem platí, že na základe univerzálneho kánonického práva duchovní pastieri nezaznačujú žiadosti katolíkov o vystúpenie z Katolíckej cirkvi do matriky. Do toho času mohol byt takýto zápis totiž realizovaný len $\mathrm{v}$ súlade s predpismi Apoštolskej Stolice o formálnom odpadnutí od Katolíckej cirkvi a po predbežnom povolení miestneho ordinára takýto dodatočný zápis alebo zmenu zápisu v niektorej z matrík farského úradu urobit. Je ale zrejmé, že v rovine partikulárneho práva môže byt táto povinnost̉ uplatňovaná nad’alej, čoho dôkazom je napríklad aj „Instrukce ohledně postupu v př́ipadech žádostí o vystoupení z církve“ vydaná v roku 2013 na skúšobnú dobu (ad experimentum) desiatich rokov brnenským diecéznym biskupom Vojtěchom Cikrle. Odhliadnuc od toho, na základe pokynov Apoštolskej Stolice alebo miestneho ordinára sa do matriky nad’alej zaznačujú cirkevné tresty exkomunikácie, suspenzie a interdiktu, ako aj potrestania prepustením z klerického stavu alebo milostou udelenou klerikovi so zámerom vyhoviet jeho prosbe prepustenia z klerického stavu a oslobodenia od povinnosti celibátu. Porov. Ján Duda, „Kto sa stal katolíkom, je navždy katolíkom," dostupné na http://duda.kapitula.sk/2010/09/kto-sa-stal-katolikom-je-navzdy-katolikom/. Najmä v krajinách, v ktorých má Cirkev charakter verejnoprávnej korporácie však platí, že záznam o odpadnutí od nej by mal byṫ urobený aj v rovine cirkevnoprávnej, ked’že štátne právo požaduje súlad medzi cirkevnou a štátnou evidenciou. Ako sme už uviedli, z pohladu Cirkvi potom väčšinou ide o rozlúčenie sa s členom v rovine schizmy alebo apostázy, prípadne herézy. Dôvodom takejto prezumpcie je nepochybne prevažujúci počet vystupujúcich, ktorí skutočne od- 
Na základe vyššie uvedeného je zrejmé, že v kánonickoprávnej praxi bolo počas existencie inštitútu formálneho úkonu odpadnutia od Katolíckej cirkvi nevyhnutné dôsledne odlišovat', za akých okolností k odpadnutiu došlo. Formálny úkon odpadnutia totiž nebol ekvivalentom verejného (publice) alebo verejne známeho (notorie) odpadnutia od katolíckej viery. ${ }^{33}$ Slovo "verejný“ sa napokon mohlo popri formálnom odpadnutí týkat' aj odpadnutia od viery prilnutím $\mathrm{k}$ inému vierovyznaniu, respektíve životu, o ktorom je verejne známe, že je v rozpore s katolíckou doktrínou, hoci bez formálneho úkonu odpadnutia. ${ }^{34}$ Pokial' ide o konkrétne príklady, ako sme už naznačili, úkonmi, pri ktorých bolo možné hovorit o formálnom odpadnutí, patrila navonok prejavená apostáza, heréza alebo schizma. Za takýto úkon bolo možné považovat' i verejné vyhlásenie o odpadnutí od katolíckej viery, ktoré bolo urobené písomne alebo ústne pred svedkami (ideálne pred cirkevnou autoritou). ${ }^{35} \mathrm{O}$ formálne odpadnutie išlo tiež v prípade katolíkov, ktorí formálne prestúpili do inej krestanskej cirkvi alebo náboženskej spoločnosti alebo k inému náboženstvu (apostáza), ak o tom existujú úradné záznamy a tie boli nejakým spôsobom intimované cirkevnej autorite. ${ }^{36}$ Takýmto spôsobom niektorí kánonisti i partikulárna prax kvalifikovala tiež členstvo katolíkov v ideologických skupinách alebo hnutiach, či or-

padli od viery v zmysle kánonu 751 CIC/1983. V týchto štátoch zároveň platí, že ak má odpadlík neskôr záujem o vyslúženie nejakého cirkevného úkonu (napríklad sviatosti alebo sväteniny), býva obvykle vyzvaný $\mathrm{k}$ úhrade príspevku na cirkevné, prípadne Cirkvi blízke účely, a to s apelom na solidaritu voči ostatným, platiacim členom. Porov. kán. 222, § 1 CIC/1983 a 25, § 1 CCEO/1990. Netreba tiež zabúdat’ na to, že kánonickoprávnym následkom akéhokolvek prehlásenia o vystúpení z Cirkvi vo vonkajšom fóre, bez ohl'adu na názov toho-ktorého inštitútu alebo jeho hodnotenie v konfesnom práve, je nielen strata nároku na služby Cirkvi, ale tiež vylúčenie z Cirkvi v právnickom rozsahu (exkomunikácia). V prípade potreby vyslúženia sviatostí je najskôr potrebné poukázat’ odpadlíkovi na možnoste návratu spät. Pokial' k takémuto kroku nie je ochotný, je na príslušnom duchovnom, aby vecne posúdil, či a za akých podmienok je vykonanie takejto služby možné. Bližšie k tejto problematike pozri napríklad Stanislav P̌̌ı IBYL, „Anketa - Budeme si církev platit sami?," Universum 2007, č. 3, s. 9.

33 Porov. NĚMEC, „Vznik, chápání a pozdější upřesnění právního institutu formálního odpadu od katolické církve," s. 242.

34 Porov. Communicationes 8 (2006): 54-56 a 10 (1978): 96-98.

35 Porov. Duda, Katolícke manželské právo, s. 172, a Jose CAsTaÑo, Il sacramento del matrimonio, II, Roma: Tipolitografia Pioda Gianfranco, 1991, s. 252.

36 Porov. Beal - Coriden - Green, New Commentary on the Code of Canon Law, s. 1336. Dlhodobé zúčastňovanie sa na kulte inej krestanskej cirkvi alebo náboženstva bez formálneho prestúpenia ani dlhodobé nepraktizovanie katolíckeho kultu v tomto prípade nestačilo. Porov. NĚMEc, Manželské právo katolické církve, s. 27. 
ganizáciách, ktorých náuka je v zásadnom rozpore s učením Katolíckej cirkvi. ${ }^{37}$ Nemožno však zabúdat na skutočnost', že ideálom zákonodarcu bolo, v duchu obežníka z roku 2006, dosiahnutie stavu, aby bol každý takýto úkon prejavený zainteresovanou osobou kompetentnej cirkevnej autorite v písomnej forme. Ked’̌̌e úmysel bol jedným z integrálnych prvkov nevyhnutných $\mathrm{k}$ formalite úkonu odpadnutia, každý prípad bolo potom potrebné preskúmat prísne individuálne. Ako sme už totiž spomenuli, napríklad v krajinách so zavedenou cirkevnou daňou, kde je jedinou cestou k uniknutiu pred jej platením vzdanie sa členstva v Cirkvi, nemusel skutočný úmysel katolíka spočívat' v snahe odpadnút od jej spoločenstva. $^{38}$

\section{Praktická aplikácia}

3.1 Výnimky v manželskom práve v rokoch 1983 až 2010

Platný Kódex kánonického práva z roku 1983 obsahuje v kánone 1117 všeobecnú zásadu, že kánonickou formou uzavierania manželstva sú viazaní všetci pokrstení v Katolíckej cirkvi alebo do nej prijatí, v rokoch 1983 až 2010 s výnimkou katolíkov, ktorí od nej odpadli formálnym úkonom. Kánonická forma sa totiž musí s účinkami pre platnost̉ dodržat’ v každom prípade, ak ide o manželstvo, $\mathrm{v}$ ktorom je aspoň jeden $\mathrm{z}$ nupturientov katolíkom, čiže aj v prípade manželstiev katolíka s nepokrstenou osobou (manželská prekážka disparitas cultus) alebo s pokrsteným ne-

37 Porov. DudA, Pokus o katolícku cirkeonoprávnu manželskú kazuistiku, s. 46, a NĚMEc, „Vznik, chápání a pozdější upřesnění právního institutu formálního odpadu od katolické církve," s. 246.

38 Aj v takomto prípade však v súlade s kánonom 124, § 2 platí prezumpcia platnosti takéhoto úkonu. Porov. NĚMec, Manželské právo katolické církve, s. 27. Podobne nemuselo byt kvalifikované ako odpadnutie od Katolíckej cirkvi formálnym úkonom ani zapísanie sa do inej cirkvi, ak bolo urobené len navonok, s ciel’om napríklad vyhoviet’ druhej manželskej strane alebo jej rodine, avšak bez skutočného zámeru opustit Katolícku cirkev. Ako sme už uviedli, z uvedeného vyplýva, že formálny úkon odpadnutia musel mat viac než len administratívnoprávny charakter (čiže odstránenie vlastného mena $\mathrm{z}$ registra členstva $\mathrm{v}$ Cirkvi vedeného štátom za účelom vyvolania istých občianskych konzekvencií), ale musel byt ponímaný ako skutočné odlúčenie sa od podstatných prvkov života Cirkvi. Porov. Caparros - Thériault - Thorn, Code of Canon Law Annotated, s. 830. 
katolíkom (miešané manželstvo). ${ }^{39}$ Jedinú výnimku z uvedeného pravidla predstavuje miešané manželstvo katolíka s pravoslávnym veriacim uzavierané pred pravoslávnym duchovným, kedže východné nekatolícke cirkvi obdobne dbajú na dodržanie kánonickej formy, považujúc manželstvo za sviatost. ${ }^{40}$ Právo východných katolíckych i nekatolíckych cirkví, na rozdiel od Latinskej (Západnej) cirkvi, navyše vyžaduje osobitný posvätný obrad kňazského požehnania manželstva, ako nevyhnutnú podmienku pre jeho uznanie za platné. ${ }^{41}$ Ako sme už spomenuli, ani skutočnost', že katolík nebol vychovaný v katolíckej viere alebo ju po krste nepraktizuje, ho z povinnosti uzavriet' manželstvo v kánonickej forme nevyníma. ${ }^{42}$ Ked’že jej dodržanie má vplyv na platnost̉ manželstva, jedinou možnostou katolíka ako sa spod nej oslobodit zostáva po roku 2010 získanie dišpenzu. ${ }^{43}$

Pokial ide o manželskú prekážku rozdielneho náboženstva (disparitas cultus), v súlade s kánonom 1086, § 1 platí, že manželstvo nemôžu pod sankciou neplatnosti uzavriet pokrstení v Katolíckej cirkvi alebo do nej

39 Bližšie k tejto problematike pozri napríklad Edward Hudson, Handbook for Marriage Nullity Cases, Ottawa: Saint Paul University, 1975, s. 58.

40 Z toho dôvodu latinské kánonické právo nepožaduje od katolíckeho veriaceho získanie dišpenzu od kánonickej formy, ale k sláveniu takéhoto manželstva postačuje dovolenie (licentia) miestneho ordinára. Porov. kán. 1127, §1 CIC/1983, a motu proprio De concordia inter Codices, Osservatore Romano 212, 16. 9. 2016, s. 4-5. Bližšie k tejto problematike pozri napríklad Duda, Katolícke manželské právo, s. 215-217.

41 Porov. kán. 828 CCEO/1990. Tí, ktorí neboli nikdy pokrstení v Katolíckej cirkvi alebo neskôr do nej prijatí, nie sú, celkom prirodzene, viazaní kánonickou formou, pokial' uzavierajú manželstvo medzi sebou. $\mathrm{V}$ takomto prípade musia pre dosiahnutie civilnoprávnych účinkov ich manželstva zachovat’ verejnú formu, ktorá je uznaná štátom (tzv. "zákonné manželstvo"). Bližšie k tejto problematike pozri napríklad NĚMEc, Manželské právo katolické církve, s. 135. Kódex kánonov východných cirkví v kánonoch 780, § 2 a 781 priamo ustanovuje, že pri manželstvách nekatolíkov sa uznáva akákolvvek forma predpísaná alebo pripustená zákonom, ktorému sú strany v čase ich slávenia podriadené. Ako je totiž všeobecne známe, cirkvi a náboženské spoločnosti pochádzajúce z protestantskej reformácie 16. storočia nedisponujú v oblasti manželského práva vlastnou normatívou (anglikánske spoločenstvo je dôležitou výnimkou) a reguláciu manželstiev v zásade ponechávajú občianskej autorite. Latinský Kódex ohladom možnej kompetencie civilnej autority $\mathrm{k}$ predpísaniu formy pre uzavieranie manželstiev medzi pokrstenými nekatolíkmi, ktoré sú v prípade uzavierania manželstiev medzi dvomi pokrstenými nekatolíkmi podla kánonického práva sviatostné, mlčí. Porov. Beal - Coriden - Green, New Commentary on the Code of Canon Law, s. 1337.

42 Porov. NĚMEC, „Vznik, chápání a pozdější upřesnění právního institutu formálního odpadu od katolické církve," s. 241.

43 Porov. kán. 1079 CIC/1983. Bližšie k tejto problematike pozri napríklad Matúš Nemec, Základy kánonického práva, Bratislava - Trnava: Iura Edition, 2006, s. 127-128. 
prijatí s osobou nepokrstenou. Aj v prípade tohto inštitútu bola v rokoch 1983 až 2010 súčastou normatívneho textu klauzula, na základe ktorej sa táto prekážka netýkala katolíka, ktorý od Cirkvi odpadol formálnym úkonom. Spod tejto manželskej prekážky však zostávajú v duchu celkového koncepčného poňatia tohto inštitútu stále vyňatí aj pokrstení nekatolíci. Túto prekážku poznajú aj východní katolíci, a to obdobne v rozmedzí sankcionovania zväzkov medzi pokrsteným katolíkom a nepokrsteným neplatnostou ${ }^{44} \mathrm{Aj} \mathrm{v}$ tomto prípade ide o normu rýdzo cirkevného práva, od ktorej môže, za splnenia podmienok stanovených kánonmi 1125 a 1126, udelit dišpenz miestny ordinár. V súvislosti s týmito normami komentáre najčastejšie upozorňujú na povinnost̉ katolíckej strany pokračovat’ $\mathrm{v}$ praktizovaní svojho náboženstva a zabezpečit katolícku výchovu detí, čo vyplýva aj z vyššie spomenutých kánonov. ${ }^{45}$ Inštitút formálneho úkonu odpadnutia od Katolíckej cirkvi bol v rokoch 1983 až 2010 aktuálny aj pri uzavieraní miešaných manželstiev (matrimonia mixta). Podl’a kánonu 1124 nebolo totiž dovolené uzavierat’ manželstvá s nekatolíkmi, pričom tento zákaz sa týkal všetkých katolíkov okrem tých, ktorí od Cirkvi odpadli formálnym úkonom. ${ }^{46} \mathrm{Aj}$ v tomto prípade analogicky platí, že dovolenie miestneho ordinára možno získat’ po splnení podmienok stanovených kánonom $1125 .{ }^{47}$

Ako sme už vo viacerých ohl'adoch naznačili, práve vágnost právnej úpravy inštitútu formálneho úkonu odpadnutia od Katolíckej cirkvi čas-

44 Porov. kán. 803 CCEO.

45 Práve katolík by mal totiž poznat potenciálne problémy, ktoré sú pri takomto zväzku vysoko pravdepodobné. Bežný protikatolícky postoj nepokrsteného alebo jeho rodiny, absentujúci rešpekt voči katolíckej viere, ako aj rozdielnost’ v prístupe $\mathrm{k}$ náboženskej praxi alebo podpore Cirkvi by mali byt’ preto nupturientmi zohl'adnené a vydiskutované ešte pred uzavretím manželstva. Porov. BeAL - Coriden - Green, New Commentary on the Code of Canon Law, s. 1345-1347.

46 K nekatolíkom zarad'ujeme členov východných cirkví, ktoré nie sú v plnom spoločenstve s Katolíckou cirkvou (východné pravoslávne a d’alšie starobylé východné cirkvi), a protestantských cirkví alebo náboženských spoločností. Medzi druhé spomenuté patria cirkvi anglikánskeho komúnia, cirkvi a náboženské spoločnosti s koreňmi v kontinentálnej protestantskej reformácii (najmä luteránske a kalvínske), valdénci, baptisti, metodisti, príslušníci kongregacionalistických cirkví a rôznych cirkví majúcich základ v rozličných protestantských úniách (napríklad Spojená cirkev Kristova pôsobiaca v USA, Spojená cirkev Kanady atd’.). Aj ked’ títo krestania nie sú v plnom spoločenstve s Katolíckou cirkvou, veria vo Svätú Trojicu, v Krista ako Božieho Syna a akceptujú Bibliu ako Božie slovo. Porov. Caparros - Thériault - Thorn, Code of Canon Law Annotated, s. 878-879.

47 Porov. Stanislav PřıbYL, Ekumenismus a právo, Brno: L. Marek, 2006, s. 153. 
to vyvolávala otázku o platnosti/neplatnosti manželstva odpadnutého/ neodpadnutého katolíka. Ak sa kánonistika nevedela zhodnút na tom, v ktorom z prípadov naozaj o takýto úkon išlo, zostával záver o posúdení platnosti takéhoto manželstva výlučne na cirkevnom sudcovi, ktorý ho posudzoval na základe vlastného vedomia a svedomia, zohl’adňujúc relevantné normy a názory ním preferovaných kánonistov (komentáre, učebnice a pod.), čo viedlo $\mathrm{k}$ značnej nejednotnosti praxe. ${ }^{48}$ Situácia sa zmenila až po roku 2006, ked’ Pápežská rada pre zákonné texty viac-menej jednoznačne ustanovila, za akých podmienok možno hovorit’ o reálnej aplikácii tohto inštitútu, čo bolo reflektované aj partikulárnym právom. Najmä v súvislosti so svojským akceptovaním tohto dokumentu však nad’alej zostáva platnost̉ manželstiev katolíkov, ktorí odpadli/ neodpadli na základe tohto inštitútu od Katolíckej cirkvi v rokoch 1983 až 2010, otáznou. V prípade ich platnosti by navyše išlo v niektorých prípadoch o sviatostné manželstvá. ${ }^{49}$ Spôsob prijatia tohto obežníka zo strany partikulárnych cirkví však $\mathrm{v}$ právnej rovine napokon až tak neprekvapuje, ked’že z dôvodu podania výkladu len v rovine kánonickoprávneho inštitútu pokynov mu chýbala zákonná sila..$^{50} \mathrm{Ak}$ nebudeme brat do úvahy prípadnú nedbanlivost' Pápežskej rady vydat tento dokument ako autentickú interpretáciu a zverejnit ju v Aktoch Apoštolskej Stolice, je nevyhnutné konštatovat', že jej zámerom bolo skutočne len poskytnutie istej oficiálnej interpretačnej pomôcky pre administratívne orgány, nie definitívneho riešenia, ktoré by bolo v rovine univerzálneho zákonodarstva záväzné aj pre cirkevných sudcov.

Aj ked' interpretácia z roku 2006 vykazuje viaceré znaky konštitutívneho výkladu, pri ktorom je retroaktivita v súlade s kánonom 16, § 2 vylúčená, tento charakter jej upiera práve jej nezverejnenie v oficiálnom

48 Porov. NĚMEc, „Vznik, chápání a pozdější upřesnění právního institutu formálního odpadu od katolické církve," s. 249.

49 Ked’že však s formálnym úkonom odpadnutia od Katolíckej cirkvi sa spája minimálne úkon schizmy, ktorá je trestaná exkomunikáciou, takýto katolík k sviatostiam pristupovat nemôže. Aj tento záver napokon vypovedá o nevhodnosti poňatia tohto inštitútu v obežníku z roku 2006. Porov. kán. 1331, § 1, 2 CIC/1983 a 1434 CCEO/1990. Bližšie k tejto problematike pozri Stefan MuCKEL, ,,Körperschaftsaustritt oder Kirchenaustritt? Der sogenannte Kirchenaustritt im Schnittfeld von staatlichem Verfassungsrecht und katholischem Kirchenrecht, " Juristenzeitung 4 (2009): 174-182.

50 Aj ked' na základe kánonu 8, § 1 sa univerzálne zákony zverejňujú v úradnom vestníku Aktov Apoštolskej Stolice, prípadne zákonodarca môže určit iný spôsob vyhlásenia, v tomto obežníku nie je uvedené nič také, z čoho by bolo možné silu zákona dedukovat'. Porov. kán. 8, §1 CIC/1983 a 1489, § 1 CCEO/1990. 
vestníku Katolíckej cirkvi. Ak by Pápežská rada zvolila tento postup, takéto riešenie by s určitostou neskomplikovalo situáciu pri rozsúdených manželských kauzách z rokov 1983 až 2006, autoritatívne by však nútila partikulárne cirkvi k detailnému zosúladeniu relevantných partikulárnych noriem s týmto obežníkom, čoho sa chcel zákonodarca zjavne vyvarovat. ${ }^{51}$ Na pozadí rýdzo cirkevného charakteru dotknutých noriem bolo $\mathrm{v}$ tejto súvislosti zároveň vel'mi tažko možné predpokladat', že by boli predmetné kauzy, napriek nemožnosti kvalifikovania statusovej veci ako res iudicata, posudzované cirkevnými sudcami nanovo. Sotva si totiž možno predstavit’, že by sa cirkevné súdy hromadne vracali v duchu interpretácie z roku 2006 k už rozsúdeným kauzám, čo napokon nie je pri obežníku s charakterom administratívneho pokynu s absentujúcou zákonnou silou a za akceptovania pravidla o zákaze retroaktivity nutné. Na strane druhej, manželstvá uzavreté katolíkmi odpadnuvšími od Katolíckej cirkvi v rokoch 2006 až 2010, by bolo možné v prípade jej charakteru ako prameňa práva posudzovat cirkevnými sudcami aj v duchu interpretácie z roku 2006..$^{52}$ Opomenúc aplikovanie tohto dokumentu cirkevnými súdmi de facto, táto možnoste prichádza do úvahy jedine v rozmere jeho prevzatia do noriem partikulárneho cirkevného práva. Aktuálnost' týchto káuz sa prejavuje, celkom prirodzene, najmä vtedy, ked' sa katolík rozhodne vrátit k praktizovaniu katolíckej viery a zvažuje uzavretie nového kánonického manželstva, čo by bolo možné, ak by jeho odpadnutie od Cirkvi nebolo kvalifikované ako formálny úkon v zmysle analyzovaných troch kánonov. ${ }^{53} \mathrm{Z}$ naznačeného tak vyplývajú viaceré

51 Ak by totiž v takomto prípade nedali partikulárne autority do toho času platné partikulárne normy upravujúce túto matériu do súladu s univerzálnym právom, boli by v odporujúcich častiach zneplatnené. Porov. Hrdina, Kanonické právo, s. 108-109.

52 Porov. NĚMEc, „Vznik, chápání a pozdější upřesnění právního institutu formálního odpadu od katolické církve," s. 248.

53 Ak katolík nenahlásil skutočnosț odpadnutia od Katolíckej cirkvi kompetentnej cirkevnej autorite (napríklad v prípade úmyslu opustit Cirkev a zaregistrovat sa v inej nekatolíckej cirkvi alebo náboženskej spoločnosti) a takéto konanie nie je právne posúdené ako formálne odpadnutie od Cirkvi, niektorí kánonisti používajú pojem „klandestínske manželstvo“, čím reflektujú skutočnosț jeho uzavretia bez vedomia cirkevnej vrchnosti. Tento výraz používa dokonca aj samotný zákonodarca v motu proprio Omnium in mentem. S používaním pojmu klandestínskych manželstiev v uvedenom kontexte však nemožno súhlasit’, ked’že tento inštitút je nevyhnutné posudzovat’ predovšetkým v predtridentskej, respektíve tridentskej kánonickoprávnej úprave. Vtedy sa ním označovali manželstvá uzavreté s úplnou absenciou verejnosti, ked' si nupturienti vymenili manželské súhlasy v súkromí. Predmetné manželstvá však boli uzavreté pred štátnym orgánom, prípadne pred orgánom inej cirkvi alebo náboženskej spoločnosti, 
komplikácie, s ktorými sa musí právna prax zoskupení jednotlivých partikulárnych cirkví vysporiadat.

\subsection{Iné prípady odpadnutia}

Ako je zrejmé z predchádzajúceho výkladu, poväčšine nebolo vôbec jednoduché kvalifikovat', za akých okolností išlo v prípade vystúpenia z Katolíckej cirkvi skutočne o odpadnutie formálnym úkonom v kánonickoprávnom zmysle. Samotný Kódex kánonického práva totiž pozná aj iné, tomuto inštitútu vel'mi podobné právne prostriedky, ktoré sa oproti nemu líšia najmä $v$ absencii povinnosti zachovania až tak vysokého stupňa formálnosti. $V$ ich prípade nie sú katolíci napríklad vôbec vyňatí spod povinnosti dodržania kánonickej formy pri uzavieraní manželstva, čo je zrejmé aj z kánonu 1071, § 1, $4^{\circ}$ Kódexu. Ten požaduje dovolenie miestneho ordinára pri uzavieraní manželstva člena Cirkvi, ktorý „všeobecne známym spôsobom zavrhol katolícku vieru" ${ }^{54} \mathrm{Aj} v$ tomto prípade je objektívne tažké určit', kedy sa odmietnutie katolíckej viery stáva všeobecne známym..$^{55}$ Problémom je tiež vymedzit pojem zavrhnutia viery, ktoré, celkom prirodzene, nemožno stotožnit s jej nepraktizovaním. Tento inštitút by však bolo s určitostou možné aplikovat̉ v prípadoch verejných vyhlásení katolíka, ktoré sú v rozpore s katolíckou vierou, alebo pridania sa $\mathrm{k}$ sekte alebo nejakej inej skupine vyvíjajúcej proticirkevnú činnost'. Takéto konanie ale $\mathrm{v}$ zásade nemožno zamieňat’ $\mathrm{s}$ formálnym úkonom odpadnutia od Cirkvi. V prípade kánonu 1071, § 1, $4^{\circ}$ totiž po-

čo im verejnost’ s určitostou zabezpečuje. Bližšie $\mathrm{k}$ tejto problematike pozri napríklad DudA, Katolícke manželské právo, s. 45, a Veronika ČunderLík Čerbová, „Tajné slávenie manželstva," in Mílniky práva v stredoeurópskom priestore 2012, Bratislava: Univerzita Komenského v Bratislave, Právnická fakulta, 2012, s. 33-39.

54 Porov. tiež kán. 1071, § 2 CIC/1983.

55 Porov. Communicationes 9 (1977): 144. Pokial ide o otázku viery nupturientov, je zrejmé, že dovolenie možno udelit len za tých okolností, ak trvá ich úprimný zámer vstúpit do manželstva a zároveň akceptujú prinajmenšom implicitne to, čo Cirkev zamýšla, ked' slávi manželstvo. Okrem toho sa vyžaduje garantovanie splnenia podmienok kánonu 1125 s primeranými úpravami. Porov. Familiaris consortio 68, in AAS 74 (1982): 81-191. Bližšie k tejto problematike pozri Caparros - Thériault - Thorn, Code of Canon Law Annotated, s. 1269. 
stačuje, ak je jasne demonštrované, že osoba zavrhla katolícku vieru vedome a že takéto zavrhnutie sa stalo verejne známym. ${ }^{56}$

Dikcia podobná vymedzeniu formálneho úkonu odpadnutia od Katolíckej cirkvi sa vyskytuje aj v kánone $194, \S 1,2^{\circ}$. Ten hovorí, že na základe práva samotného (ipso iure) strácajú cirkevný úrad tí, ktorí „verejne odpadli od katolíckej viery alebo spoločenstva s Cirkvou“. V tomto prípade je, samozrejme, užitočné, ak je takéto konanie posúdené kompetentnou cirkevnou autoritou, ktorej vyhlásenie má však len deklaratórny charakter. Tento akt preto nie je právom vyžadovaný s cielom dosiahnutia uprázdnenia cirkevného úradu, ale za účelom právnej istoty a možnosti udelenia úradu držitel'ovi novému. ${ }^{57}$ Ked’že takéto konanie držitela úradu je zároveň deliktom, aj samotná strata úradu má trestnoprávny charakter ${ }^{58}$ Verejné odpadnutie od katolíckej viery je v tomto ohlade podobné, aj ked' nie úplne totožné, s pojmom apostáza, ktorá predstavuje v súlade $\mathrm{s}$ kánonom 751 odmietnutie krestanskej viery ako celku..$^{59}$ Ani v prípade kánonu 194, $§ 1,2^{\circ}$ sa tak nevyžaduje formálny úkon odpadnutia od Katolíckej cirkvi. Jedinou požiadavkou je, aby išlo o úkon verejný, ktorý je bud' známy, alebo sa pravdepodobne známym stane. Obdobne sa nežiada ani to, aby sa držitel' úradu pridal $\mathrm{k}$ inému náboženstvu, hoci takéto konanie by bolo $\mathrm{v}$ zmysle tohto kánonu s ur-

56 Toto chápanie termínu „verejne známy“ je prevzaté z kánonu 2197, 3 Kódexu kánonického práva z roku 1917, kde sa hovorí o verejne známych deliktoch. Podla jeho dikcie je delikt všeobecne verejne známy, ak bol spáchaný za takých okolností, že ho nie je možné zakryt žiadnou výhovorkou, ani ospravedlnit pomocou práva. V latinskom origináli: „Notorium notorietate facti, si publice notum sit et in talibus adiunctis commissum, ut nulla tergiversatione celari nulloque iuris suffragio excusari possit." Porov. kán. 2197, $3^{\circ}$ CIC/1917.

57 Porov. kán. 154 a 194, § 2 CIC/1983 a 944 CCEO/1990.

58 Tento kánon predstavuje výnimku z trestného zákona, ked’že odňatie úradu je kánonistikou kvalifikované ako stály odpykávací trest (kán. 1336, §1, $2^{\circ}$ CIC/1983), ktorý nemôže byṫ uložený alebo deklarovaný dekrétom (kán. 1342, § 2 a 1402, § 2 CCEO/1990). Kompetentná cirkevná autorita preto musí pred vydaním dekrétu zozbierat všetky relevantné fakty týkajúce sa kauzy a poskytnút držitelovi úradu možnost’ vyjadrit sa (kán. 50 CIC/1983 a 1517, § 1 CCEO/1990). Porov. kán. 51 CIC/1983 a 1514 a 1519, § 2 CCEO/1990.

59 Pod odpadnutím od viery (apostasia a fide) je potrebné rozumiet úplné zavrhnutie dobrovolne prijatej viery, a to vnútorne (forum internum) i navonok (forum externum). Tento pojem pritom nemožno stotožňovat' so schizmou, ktorá je odpadnutím od katolíckeho spoločenstva ( $\mathrm{v}$ tomto prípade partikulárnej cirkvi a svojho biskupa) a prejavuje sa v odmietaní podriadenia sa najvyššiemu vel'kňazovi alebo spojenia s členmi Cirkvi jemu podriadenými. Porov. kán. 751 CIC/1983. 
čitostou kvalifikované ako objektívny znak odpadnutia. ${ }^{60}$ Podobným prípadom je i norma kánonu 694, § 1, 1ํ․ ktorá hovorí o členovi prepustenom z inštitútu zasväteného života ipso facto, $\mathrm{k}$ čomu dochádza, ak „verejne známym spôsobom odpadol od katolíckej viery“. Aj tu je dôležitý dôkaz o uskutočnení takéhoto konania vo vonkajšom fóre. Celkom prirodzene ani $\mathrm{v}$ tomto kontexte nepostačuje len kritické vyjadrovanie sa na adresu cirkevnej náuky alebo praxe. Odpadnutie verejne známym spôsobom by sa ale s určitostou týkalo rehol'níka, ktorý sa pridal k inej nekatolíckej alebo nekrestanskej komunite, úplne nahrádzajúc verejný kult Katolíckej cirkvi. ${ }^{61}$

Od formálneho úkonu odpadnutia od Katolíckej cirkvi je potrebné odlíšit aj kánonickoprávne vymedzenie nespôsobilosti hlasovat’ v kánonickej vol'be podl'a kánonu $171, \S 1,4^{\circ}$. Ten $\mathrm{v}$ taxatívnom výpočte uvádza aj osobu, ktorá „verejne odpadla od spoločenstva Cirkvi“. Odpadnutie musí byt aj v tomto prípade verejné, pričom takýto úkon býva $\mathrm{v}$ záujme právnej istoty dodatočne deklarovaný kompetentnou cirkevnou autoritou, alebo naozaj všeobecne známe. Ani pri tomto inštitúte sa teda nevyžaduje opustenie Cirkvi formálnym úkonom alebo pridanie sa $\mathrm{k}$ inej cirkvi alebo náboženskej spoločnosti či náboženstvu. $\mathrm{V}$ prípade, ak existujú pochybnosti o platnosti vykonanej vol'by, na základe tohto bodu nebude postačovat len podozrenie, že hlasujúci je odpadlíkom v zmysle vyššie uvedeného kánonu, ked’že právo výslovne požaduje dôkaz o skutku. ${ }^{62}$ Ako d’alší príklad možno spomenút kánon 316, ktorý ustanovuje, že do verejných združení nemôže byt' platne prijatý ten, kto „verejne zavrhol katolícku vieru, odpadol od cirkevného spoločenstva, alebo je postihnutý uloženou alebo vyhlásenou exkomunikáciou“.63 $\mathrm{Aj}$ v tomto prípade predstavuje najväčší problém posúdenie, ktorým okamihom osoba verejne zavrhla katolícku vieru alebo opustila spoločenstvo s Cirkvou. Z pohl’adu praxe prichádza táto možnost̉ do úvahy pri zavrhnutí katolíckej viery verejne známym spôsobom, prípadne vtedy,

60 Beal - Coriden - Green, New Commentary on the Code of Canon Law, s. 226-227.

61 Bližšie k tejto problematike pozri napríklad Bronisław ZuBERT, Řeholní právo: Instituty zasvěceného života a společnosti apoštolského života, Olomouc: Matice Cyrilometodějská, 1996, s. 298n.

62 Porov. Communicationes 14 (1982): 152.

$63 \S 2$ tohto kánonu potom spresňuje, že tí, o ktorých sa hovorí v §1, sa majú po predchádzajúcom napomenutí zo združenia prepustit pri zachovaní jeho štatútu a pri neporušení práva rekurzu k cirkevnej vrchnosti, na ktoré odkazuje kánon 312 , §1. Porov. kán. 316, §§ $1-2$ a 580 CCEO/1990. 
ak sa katolík nejakým verejne známym spôsobom vzdialil od cirkevného spoločenstva. K prvému prípadu môže dôjst', napríklad ak člen Cirkvi verejne konvertuje od katolíckej viery $\mathrm{k}$ inej konfesii (napríklad vstúpi do Evanjelickej cirkvi), k druhému vtedy, ak opustí spoločenstvo s Katolíckou cirkvou bez toho, aby sa pridal $\mathrm{k}$ inej cirkevnej komunite. Samotný fakt nepraktizovania viery však, celkom prirodzene, k naplneniu skutkovej podstaty tejto normy nepostačuje. ${ }^{64}$

\section{ZÁver}

Ako sme uviedli, vydanie motu proprio Omnium in mentem bolo výsledkom dlhoročných prác členov Pápežskej rady pre zákonné texty a d’alších odborníkov Rímskej kúrie (curia Romana), ktorí napokon dospeli k záveru, že inštitút formálneho úkonu odpadnutia od Katolíckej cirkvi sa neosvedčil nielen v cirkevnoprávnej, ale ani v pastoračnej praxi. ${ }^{65} \mathrm{Aj}$ ked' sa totiž spočiatku malo za to, že jeho existencia je opodstatnená a je potrebné predchádzat tomu, aby odpadnuvší katolíci žili v neplatných manželstvách, $\mathrm{k}$ značným problémom dochádzalo najmä po ich návrate do Cirkvi. ${ }^{66}$ Ich manželstvo bolo totiž podla kánonické-

64 Porov. Caparros - Thériault - Thorn, Code of Canon Law Annotated, s. 260.

65 Porov. Omnium in mentem, pr.

66 Porov. NĚMEC, „Vznik, chápání a pozdější upřesnění právního institutu formálního odpadu od katolické církve," s. 242. V tejto súvislosti je potrebné si uvedomit', že v prípade pochybností o platnosti manželstva uzavretého/neuzavretého po formálnom úkone odpadnutia/neodpadnutia od Katolíckej cirkvi, platí nielen domnienka o formálnom odpadnutí od Katolíckej cirkvi v rozmere predmetného inštitútu, ale tiež domnienka o platnosti takýchto manželstiev, ked’že manželstvo $\mathrm{v}$ zásade požíva priazeň práva (favor iuris). Na tomto pozadí sa v praxi bežne stáva, že tieto manželstvá nie je možné cirkevným súdom po návrate katolíka spät do Cirkvi (s ohladom na predchádzajúci úkon formálneho odpadnutia) dôkladne posúdit a z toho dôvodu sa na ne musí pozerat' ako na platné, napriek tomu, že objektívny skutkový stav môže byt' iný. Uzavretie nového kánonického manželstva preto nebude takejto osobe cirkevnou autoritou umožnené, skôr jej bude ponúknutá možnost’ splatnenia predchádzajúceho manželstva, o ktorého platnosti by eventuálne existovali nejaké pochybnosti. Kým v individuálnom prípade do úvahy prichádza jednoduchá konvalidácia manželstva, v prípade všetkých takýchto manželstiev na určitom území by do úvahy prichádzalo použitie inštitútu sanácie v základe (sanatio in radice), ktorý bol historicky viackrát aplikovaný k splatneniu manželstiev neplatných z dôvodu nedodržania kánonickej formy na pozadí rozporov medzi kánonickoprávnou a konfesnoprávnou legislatívou. Pri neplatných manželstvách by navyše katolíci neboli celkom pripravení o možnost̉ rozhodnút 
ho práva $\mathrm{v}$ dôsledku tohto inštitútu považované za platné, hoci o jeho platnosti mohli opodstatnene existovat viaceré pochybnosti. Mnohokrát sa totiž v praxi stávalo, že v prípade zdanlivého naplnenia podmienok formálneho úkonu odpadnutia od Katolíckej cirkvi, nastúpila namiesto ich reálneho posúdenia len vyvrátitelná domnienka, že to tak naozaj bolo. Celkom prirodzene v prípade tohto motu proprio ako normatívneho právneho aktu neprichádza do úvahy spätná účinnost', a preto manželstvá uzavreté katolíkmi, ktorí odpadli od Cirkvi formálnym úkonom v rokoch 1983 až 2010, zostávajú v stave ich posúdenia právnou praxou v rozmedzí vtedajšej právnej úpravy ${ }^{67}$

Ďalšou velmi podstatnou pohnútkou k vydaniu motu proprio Omnium in mentem bola snaha zosúladit teologické aspekty tohto inštitútu $\mathrm{s}$ aspektmi právnymi. ${ }^{68} \mathrm{Ak}$ totiž raz niekto prijal krst v Katolíckej cirkvi, prípadne bol do nej neskôr prijatý, neexistuje nijaký spôsob, ako z nej vystúpit $\mathrm{v}$ teologickom zmysle. ${ }^{69}$ Sviatostné puto prináležania $\mathrm{k}$ Telu Krista, ktorým je Cirkev, udelené znakom krstu, je napokon ontologickým a večným putom, ktoré nie je možné stratit $\mathrm{v}$ dôsledku akéhokolvek kánonickoprávneho alebo iného úkonu. ${ }^{70} \mathrm{Z}$ toho dôvodu platí, že vystúpenie z Katolíckej cirkvi a ukončenie príslušnosti $\mathrm{k}$ nej, tak ako to chápe konfesné právo niektorých štátov, nie je $\mathrm{v}$ kánonickom práve možné. Tieto teologické a doktrinálne fakty zohladňuje vd’aka spomenutému motu proprio po roku 2010 dôslednejšie aj cirkevná legislatíva. Z pohladu záväznosti noriem rýdzo kánonického práva prispelo zrušenie tohto inštitútu zároveň k obnoveniu bezpodmienečnej platnosti

sa pre zotrvanie alebo nezotrvanie v manželstve, ked’že pri použití tohto inštitútu je kvalifikované ako condicio sine qua non trvanie manželských súhlasov oboch strán, ktoré musí byt’ aktuálne v čase jeho aplikácie. Porov. napríklad Hrdina, Kanonické právo, s. 310.

67 Takéto manželstvá možno kánonicky preskúmat̉ len s ohl’adom na dodržanie noriem prirodzeného a pozitívneho Božieho práva, avšak nie pokial ide o dodržanie kánonickej formy jeho uzavierania, spod ktorej boli takíto katolíci zákonom uvolnení. Samozrejme aj v tomto prípade sa v prvom rade predpokladá dodržanie nejakej verejnej formy slávenia manželstva v záujme dokázania jeho platného uzavretia mimo Katolícku cirkev. Porov. Jiř́ KAŠnÝ, Manželstoí v západní tradici: Soubor kanonických studií, České Budějovice: Jihočeská univerzita v Českých Budějovicích, 2006, s. 65.

68 Porov. Omnium in mentem, pr.

69 Ako je všeobecne známe, krst patrí medzi sviatosti, ktoré vtláčajú do duše nezmazatelný znak (character indelebilis) a z toho dôvodu sú neopakovatel'né. Porov. napríklad Jiří Rajmund Tretera - Záboj Horák, Slovník církevního práva, Praha: Grada, 2011, s. 72.

70 Porov. NĚMEC, „Vznik, chápání a pozdější upřesnění právního institutu formálního odpadu od katolické církve," s. 249. 
kánonu 11, ktorý tak opätovne nadobudol svoju plnú moc aj vo vzt̉ahu $\mathrm{k}$ dotknutým trom kánonom kánonického manželského práva. ${ }^{71}$ Pri analýze inštitútu formálneho úkonu odpadnutia od Katolíckej cirkvi možno paradoxne konštatovat', že najväčší zásah do jeho praktického uplatňovania a zároveň najviac praktických komplikácii spôsobila spomínaná interpretácia Pápežskej rady pre zákonné texty z roku 2006. Práve tento obežník, ako býva uvedený dokument bežne v kánonistike označovaný, totiž priniesol také zúženie výkladu predmetných noriem, že to viedlo nielen $\mathrm{k}$ značnému zhoršeniu ich použitel'nosti $\mathrm{v}$ praxi, ale neskôr tiež $\mathrm{k}$ nevyhnutnosti zrušenia vsuviek odkazujúcich na tento inštitút. Novost výkladu Pápežskej rady z roku 2006 pritom spočívala najmä vo vyžadovaní posudzovania vnútorných pohnútok vôle vystupujúceho, z čoho možno dedukovat jasný záujem zákonodarcu obmedzit počet katolíkov vystupujúcich z Katolíckej cirkvi na základe formálneho úkonu odpadnutia na minimum. ${ }^{72}$

Na záver možno konštatovat', že najväčší problém obežníka z roku 2006 spočíval v skutočnosti, že Pápežská rada v ňom podala interpretáciu len v rozmere úradného (oficiálneho) výkladu s charakterom pokynov, ktoré nemajú charakter prameňa práva a sú záväzné len pre podriadené administratívne orgány. $Z$ toho možno dedukovat', že jej zámerom s určitostou nebolo definitívne zosúladenie praxe riešenia týchto káuz. Zákonodarcu $\mathrm{k}$ tomuto opatrnému postupu zrejme viedla predovšetkým obava z reakcií jednotlivých partikulárnych cirkví, a to najmä sebavedomých predstavitel'ov cirkví v nemecky hovoriacich krajinách so zavedenou cirkevnou daňou, $\mathrm{v}$ ktorých bola prax do toho času značne rôznorodá. $V$ inom prípade by totiž postupoval cestou riadne publikovanej autentickej interpretácie v rozmere výkladu s konštitutívnymi účinkami, predstavujúceho legislatívne doplnenie zákona. Aj napriek vyššie uvedenému postupu však možno konštatovat', že zákonodarcovi sa v zásade podarilo dosiahnut transformáciu väčšiny týchto „odporúčaní" do partikulárneho kánonického práva, $\mathrm{k}$ čomu došlo, aj ked’ častokrát vo

71 Porov. Omnium in mentem, pr. a 3-5.

72 Okrem toho, údajne existovali tiež obavy, aby odpadnuvší katolíci, ktorí by sa navracali spät’ do Katolíckej cirkvi po tom, čo sa im nepodarilo uzavriet’ platné manželstvo (mimo Cirkev), neopustili svoju manželku a deti s výhovorkou neplatnosti manželstva. Porov. Peters, "The Formal Act of Defection," dostupné na http://www.canonlaw.info/canonlaw_discus.htm. 
svojskej forme, najmä v nemecky hovoriacich krajinách. ${ }^{73} \mathrm{Na}$ príklade tohto inštitútu možno zároveň spätne poukázat’ na to, akým spôsobom môže partikulárna cirkevná legislatíva a najmä konfesné zákonodarstvo jednotlivých štátov ovplyvnit’ správanie univerzálneho zákonodarcu. ${ }^{74}$

\section{Defection from Communion with the Catholic Church by a Formal Act}

Keywords: Catholic Church; Formal Act of Defection; Membership; Canon Law; Legislative Changes; Circular Letter; Omnium in mentem; Legal Effects; Theology; Church Tax

Abstract: Issues concerning leaving the Catholic Church are still very much current at this time, especially in European states with an instituted Church tax. Assuming the characters of the formal act of defection from the Catholic Church are met, individual legal effects connected with such acts are also in the area of marriage law, which represented the excep-

73 Ako sme už spomenuli, najd’alej v tomto ohl’ade zašla Rakúska biskupská konferencia (ÖBK), ktorá obežník z roku 2006 publikovala v roku 2007 v oficiálnom vestníku a stal sa tak súčastou rakúskeho partikulárneho práva. Kvôli tomu tiež rakúski biskupi ustanovili už spomenutú povinnost’ akéhosi opytovacieho konania, ktoré muselo nasledovat zo strany predstavitel'ov príslušnej diecézy v okamihu, ked' sa dozvedeli o vystúpení katolíka z Cirkvi. Tento postup sa podstatne líšil od predchádzajúcej praxe v tom, že medzi okamihom ohlásenia vystúpenia katolíka z Cirkvi štátnym úradom a jeho záznamom v cirkevnej matrike, prebehlo práve spomenuté konanie, ktorého úlohou bolo vyjasnenie motívov vystupujúceho. Partikulárna úprava, ktorú zvolila Rakúska biskupská konferencia, tak na cirkevnej úrovni nanovo prehodnocovala štátny akt vystúpenia z Cirkvi, na základe čoho sa nahradila dovtedajšia prax, ked' bol každý takýto výstup považovaný za formálny úkon odpadnutia. S vystúpením z Cirkvi sa spájajú i viaceré paradoxné situácie, ked’ dochádza k odlišným právnym účinkom tohto inštitútu v štátnom a kánonickom práve. Štát tak napríklad osobitne nanovo eviduje ako člena Katolíckej cirkvi osobu, ktorá po vystúpení z Cirkvi do nej opätovne vstúpila. Z cirkevného hladiska však v tomto prípade nešlo o prerušenie členstva, a to aj napriek tomu, že štát prikazuje Cirkvi takúto osobu zaevidovat ako nového člena. Bližšie k tejto problematike pozri Georg BIER, „,Was ist der Kirchenaustritt? Neue Entwicklungen in einer altbekannten Frage," Herder Korrespondenz 7 (2006): 350n., a Urbano NavarRETE, „Disparitas cultus (kán. 1086), “ in Diritto matrimoniale canonico, I, Studi giuridici LVI., Città del Vaticano: Libreria Editrice Vaticana, 2002, s. 531.

74 Vydanie tejto interpretácie s ohl’adom na vtedajší stav predmetných káuz v určitých štátoch a tamojších partikulárnych cirkvách naznačuje i dikcia tohto dokumentu, ktorá bežne pracuje s pojmami ako "administratívnoprávny charakter formálneho úkonu odpadnutia od Katolíckej cirkvi“, „,odstránenie mena z registra členstva v cirkvi vedeného štátom“ a pod. Porov. Pontificium Consilium de legum textibus, „Actus formalis defectionis ab Ecclesia catholica," dostupné na http://www.vatican.va/roman_curia/ pontifical_councils/intrptxt/documents/rc_pc_intrptxt_doc_20060313_actus-formalis_ en.html. 
tion from the established principle of "once a Catholic, always a Catholic". These questions also, due to the vagueness of the legal definition of this institution, infringed on the principle of legal certainty in a number of aspects. The universal lawgiver proceeded on this account to its specification in 2006, with this also being reflected by the rules of particular canon law, and in 2010 to its abrogation. When considering leaving the Catholic Church, the numbers did not decrease drastically in the majority of countries. Regardless of the name of the given institution, a Catholic does not stop being a member of the Church and is henceforth bound by its rules, according to the theological and doctrinal conclusions, as well as the valid canon-law regulations. The main goal of this article is to define the basic concepts, point out the various controversies connected with the application of the institution of the formal act of defection and the coherent legislative changes, including their impact on particular Church practice.

doc. JUDr. Mgr. Vojtech Vladár, PhD. Katedra rímskeho a cirkevného práva Právnická fakulta

Trnavská univerzita $\mathrm{v}$ Trnave

Hornopotočná 23

91843 Trnava

vojtech.vladar@truni.sk 